\title{
How West African countries prioritize health
}

\author{
Yusuff Adebayo Adebisi ${ }^{1,2,3^{*}}$, Aishat Alaran ${ }^{4}$, Abubakar Badmos ${ }^{5}$, Adeola Oluwaseyi Bamisaiye ${ }^{3,6}$, \\ Nzeribe Emmanuella ${ }^{7}$, Alison Ubong Etukakpan ${ }^{8}$, Iyiola Olatunji Oladunjoye ${ }^{9}$, Oladipo Oluwaseyifunmi ${ }^{10}$, \\ Shingin Kovona Musa ${ }^{11}$, Temiwunmi Akinmuleya ${ }^{3}$, Omotayo Carolyn Olaoye ${ }^{12}$, \\ Obafemi Arinola Olarewaju ${ }^{13}$ and Don Eliseo Lucero-Prisno III $^{2,14}$
}

\begin{abstract}
Background: The goal of Universal Health Coverage (UHC) is to ensure that everyone is able to obtain the health services they need without suffering financial hardship. UHC remains a mirage if government health expenditure is not improved. Health priority refers to general government health expenditure as a percentage of general government expenditure. It indicates the priority of the government to spend on healthcare from its domestic public resources. Our study aimed to assess health priorities in the Economic Community of West African States (ECOWAS) using the health priority index from the WHO's Global Health Expenditure Database.
\end{abstract}

Method: We extracted and analysed data on health priority in the WHO's Global Health Expenditure Database across the 15 members of the ECOWAS (Benin, Burkina Faso, Cabo Verde, Cote d'Ivoire, The Gambia, Ghana, Guinea, GuineaBissau, Liberia, Mali, Niger, Nigeria, Senegal, Sierra Leone, and Togo) from 2010 to 2018 to assess how these countries prioritize health. The data are presented using descriptive statistics.

Results: Our findings revealed that no West African country beats the cutoff of a minimum of $15 \%$ health priority index. Ghana (8.43\%), Carbo Verde (8.29\%), and Burkina Faso (7.60\%) were the top three countries with the highest average health priority index, while Guinea (3.05\%), Liberia (3.46\%), and Guinea-Bissau (3.56\%) had the lowest average health priority in the West African region within the period of our analysis (2010 to 2018).

Conclusion: Our study reiterates the need for West African governments and other relevant stakeholders to prioritize health in their political agenda towards achieving UHC.

Keywords: Health financing, Health systems, Universal Health Coverage, ECOWAS, West Africa

\section{Introduction}

Health systems in Sub-Saharan Africa including West Africa have long been plagued with a double burden of communicable and non-communicable diseases [1] and presently, the COVID-19 pandemic [2]. Despite the advancement in health across the world, the region continues to lag behind. There is at least a decade difference in the life expectancies in the African region compared to other regions of the world. This is in part due to the

\footnotetext{
*Correspondence: adebisi.adebayo@ghfocus.org

1 African Young Leaders for Global Health, Abuja, Nigeria

Full list of author information is available at the end of the article
}

weak healthcare systems [3]. Although the global maternal mortality rate fell by $44 \%$ between 1990 and 2015, $99 \%$ of the global maternal mortality rate is now being accounted for in the developing world with over $66 \%$ of the cases being reported in West Africa and other subSaharan African countries [4]. The infant and under-five mortality rates are also comparable; while there have been a massive decline in the world under-five mortality rates (59\% decrease from 1990 to 2019), the statistic is not very promising in sub-Saharan Africa, as the region accounts for the highest under-five mortality rates in the world $[5,6]$. One in 13 children in the region dies before the age of 5 [5]. The HIV epidemic also continues original author(s) and the source, provide a link to the Creative Commons licence, and indicate if changes were made. The images or other third party material in this article are included in the article's Creative Commons licence, unless indicated otherwise in a credit line to the material. If material is not included in the article's Creative Commons licence and your intended use is not permitted by statutory regulation or exceeds the permitted use, you will need to obtain permission directly from the copyright holder. To view a copy of this licence, visit http://creativecommons.org/licenses/by/4.0/. 
to disproportionally affect the region, with insufficient antiretroviral treatment and AIDS-related complications playing a huge role in infant mortality and reduced life expectancy $[7,8]$.

This huge disparity and the persistence of ill-health in the region are not due to the dearth of initiatives or policies to reform the healthcare system. Every decade, since the 1940 s has seen health policymakers, professionals, and providers launch global and national initiatives to address the growing health challenges and needs of people living in sub-Saharan Africa. However, only a few have had any success [1]. The Abuja Declaration made in 2001 remains one of the most significant, where the government of the African Union countries met and pledged to allocate at least $15 \%$ of their budget to health to address the massive burden of health problems facing countries in Africa, particularly within the context of a growing burden of HIV, AIDS, TB, and malaria [9]. However, two decades after the declaration, only three countries were listed as making progress towards the pledge $[3,10]$. The countries are Rwanda, Botswana, and Zambia, with no countries in West Africa. More recently, the high-level task force on Innovative Financing for Health system (HLTF) recommended that low-income countries needed at least 44 USD per capital to deliver an essential package of health services $[3,11]$. For sub-Saharan Africa to meet the target of the Universal Health Coverage (UHC) and Sustainable Development Goals (SDGs) by 2030 , the countries need to increase the government general health expenditure from an average of $5.6 \%$ to $7.5 \%$, and this would require at least 371 billion US dollars yearly to bridge the gap [12].

Despite the benefits health insurance has reaped for healthcare in many high-income countries, African countries including West African countries still struggle with the implementation and sustainability of effective and efficient health insurance systems [3]. A protocol for systematic review revealed that even though there are numerous studies on the impact of health insurance on access to medical services, few have considered West Africa as a whole [6]. Despite many years of investments and targeted work by the government and private insurance establishments, West African countries continue to suffer from significant out-of-pocket payment for healthcare [3]. While it has never been more critical for governments in the region to be more committed to improve the healthcare status of their people and meet international goals, efforts towards this remain grossly insufficient. West African government needs to prioritize healthcare for several reasons. First, health is a human right that every citizen of every country should have access to. Second, good health is a prerequisite to the human development and economic growth of any country [13]. Third, national health systems in West Africa are underfunded and the adequate manpower to efficiently run the healthcare system is not available [14, 15]. In addition, healthcare system readiness and proper functioning are important in combating epidemics and pandemics. The government's commitment to healthcare in this region has been a subject under constant scrutiny, because even if there is a fixed target for the amount government spends on health, there is a need for robust data and monitoring of government health spending. The levels of government health expenditure (in absolute terms and as a share of the gross domestic product and overall budget) indicate government commitment to health [11].

For West African countries to move towards the target of UHC, healthcare systems need to be adequately strengthened. Out-of-pocket payment has driven many people below the poverty line $[3,16]$. This is not in line with the goal of UHC, as access to needed health services should not expose individuals to financial hardship. A key element of the UHC includes financial protection from the costs of ill health and access to and use of needed health services within a country. Thus, reducing the reliance on out-of-pocket payments for healthcare is important for financial protection [16]. This makes the government's health expenditure critical to the achievement of the objectives of UHC, as a considerable increase in government expenditure on health will drastically reduce out-of-pocket payments and increase the financial protection of the populace.

West Africa is characterized by much diversity in terms of demographics, and health outcomes among others (see Table 1). These factors have not only contributed to the differences in the health status of the region's diverse populations but also to the diverse nature of its health systems. Therefore, this study aimed to assess health priorities using the government health expenditure and the general government expenditure in the Economic Community of West African States (ECOWAS) from 2010 to 2018.

\section{Method}

We extracted and analysed data from 2010 to 2018 on health priority (the share of domestic general government health expenditures of general government expenditure) in the WHO's Global Health Expenditure Database (https://apps.who.int/nha/database/country profile/Index/en) across the 15 members of the ECOWAS (Benin, Burkina Faso, Cabo Verde, Cote d'Ivoire, The Gambia, Ghana, Guinea, Guinea-Bissau, Liberia, Mali, Niger, Nigeria, Senegal, Sierra Leone, and Togo) (see Fig. 1). The data available from the WHO Global Health Expenditure database are reported by country governments using the framework of System of Health 
Table 1 Total population and selected health indicators in ECOWAS. Source: Authors compilation from Global Health Observatory Database. Accessed link: https://www.who.int/data/gho/data/indicators Accessed 29 Sept 2021

\begin{tabular}{|c|c|c|c|c|c|c|}
\hline Country/Indicator & $\begin{array}{l}\text { Total population (in } \\
\text { thousands) - } 2016\end{array}$ & $\begin{array}{l}\text { Life expectancy } \\
\text { at birth (years)- } \\
2019\end{array}$ & $\begin{array}{l}\text { Under-five } \\
\text { mortality rate } \\
\text { (probability of } \\
\text { dying by age } \\
5 \text { per } 1000 \text { live } \\
\text { births)-2019 }\end{array}$ & $\begin{array}{l}\text { Maternal } \\
\text { mortality ratio } \\
\text { per } 100,000 \text { live } \\
\text { births-2017 }\end{array}$ & $\begin{array}{l}\text { Total NCDs age- } \\
\text { standardized } \\
\text { mortality rate } \\
\text { (per 100,000 } \\
\text { population)-2019 }\end{array}$ & $\begin{array}{l}\text { Out-of-pocket } \\
\text { expenditure as } \\
\text { percentage of } \\
\text { current health } \\
\text { expenditure } \\
\text { (\%)-2018 }\end{array}$ \\
\hline Benin & 10,872 & 63.43 & 90.29 & 397 & 569.8 & 44.55 \\
\hline Ghana & 28,207 & 66.28 & 46.16 & 308 & 551.1 & 37.69 \\
\hline Nigeria & 185,990 & 62.62 & 117.2 & 917 & 512.3 & 76.60 \\
\hline Burkina Faso & 18,646 & 62.70 & 87.54 & 320 & 566.3 & 35.83 \\
\hline Cabo Verde & 540 & 74.03 & 14.86 & 58 & 405.8 & 27.96 \\
\hline Cote d'Ivoire & 23,696 & 62.92 & 77.50 & 617 & 527.5 & 39.43 \\
\hline The Gambia & 2039 & 65.47 & 51.72 & 597 & 553.7 & 29.34 \\
\hline Liberia & 4614 & 64.08 & 84.62 & 661 & 484.3 & 41.79 \\
\hline Togo & 7606 & 64.27 & 66.90 & 396 & 558.4 & 56.32 \\
\hline Mali & 17,995 & 62.80 & 94.04 & 562 & 604.1 & 33.90 \\
\hline Niger & 20,673 & 63.29 & 80.37 & 509 & 575.8 & 48.79 \\
\hline Senegal & 15,412 & 68.58 & 45.31 & 315 & 529.5 & 55.89 \\
\hline Guinea & 12,396 & 61.01 & 98.8 & 576 & 632.1 & 60.62 \\
\hline Sierra Leone & 7396 & 60.77 & 109.2 & 1120 & 631.8 & 44.78 \\
\hline Guinea-Bissau & 1816 & 60.22 & 78.47 & 667 & 604.8 & 74.48 \\
\hline
\end{tabular}

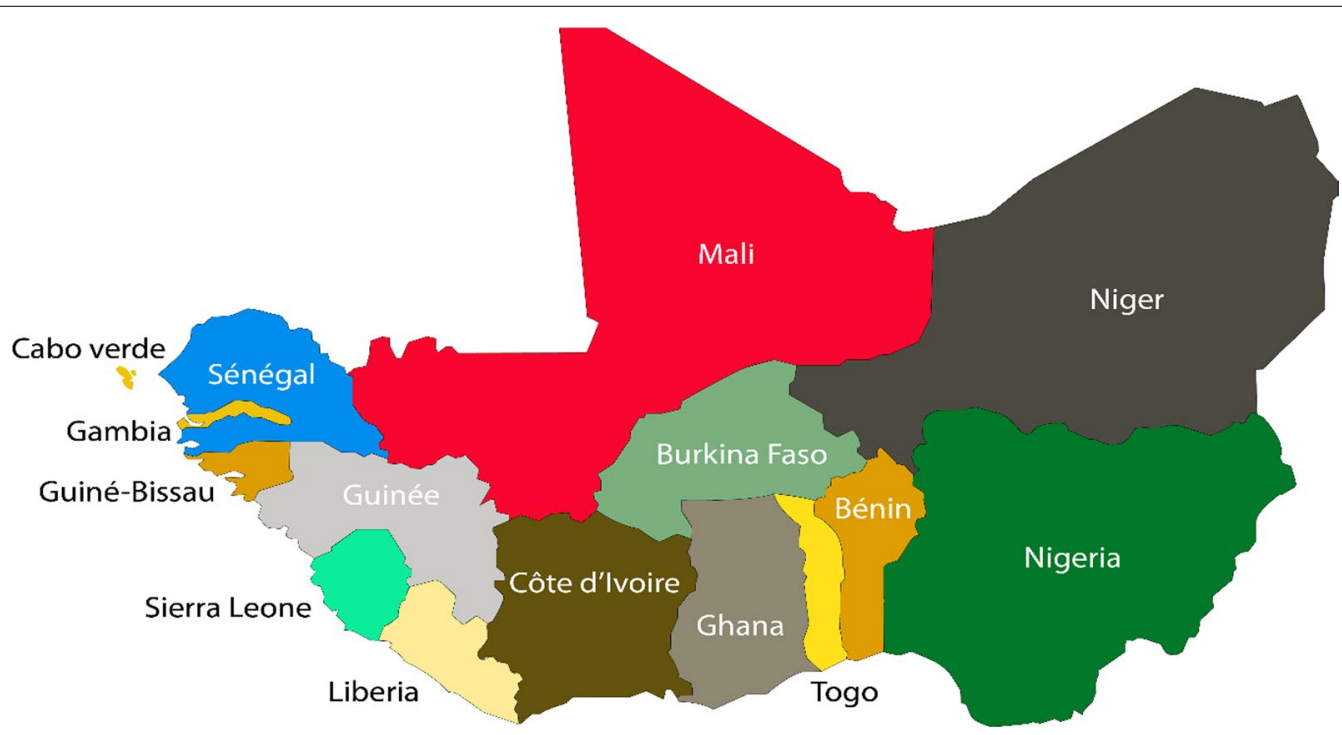

Fig. 1 Illustration showing ECOWAS member states

Accounts 2011. The database provides internationally comparable data on health spending for close to 190 countries including West African countries from 2000 to 2018. The database is open access, and it supports the goal of UHC by assisting in monitoring the availability of resources for health and the extent to which they are used efficiently and equitably. We considered the years
2010-2018, because it covers certain parts of the Millennium Development Goals (MDGs) and Sustainable Development Goals (SDGs) era. This provides an insight into the progress made in improving health across West Africa over time.

We also identified that the ideal health priority index should be equal to a minimum of $15 \%$, considering the 
formula $=$ (government health expenditure over government total expenditure) $\times 100$. The minimum government health expenditure should be $15 \%$ [3]. That implies the net government expenditure should be set at $100 \%$ (minimum of $15 \%$ to health; minimum of $85 \%$ to other areas). Then, health priority $=(15 \% / 100 \%) \times 100=15 \%$. We summarized health priorities across 15 countries in ECOWAS from 2010 to 2018 and compared the average health priorities to the minimum of an ideal health priority index of $15 \%$. The data are presented using descriptive statistics.

\section{Results}

Table 2 shows health priorities across West African countries from 2010 to 2018. Our findings revealed that Ghana has the highest average health priority $(8.29 \%)$, while Guinea has the lowest average health priority (3.05\%) in the West African region within the period of our analysis.

Figure 2 also reveals that no West African countries beat the cutoff of a minimum of $15 \%$ health priority index.

\section{Discussion}

State of health priority in West Africa

Amidst the increasing cost of health services globally and escalating prevalence of endemic and epidemic diseases plaguing the West African subcontinent, the health priority of ECOWAS countries remains inadequate. Expressed in percentage as the government expenditure on health over the total expenditure, the health priority of each country is used as a tool to determine the level of prioritization of health by the governments through their budgetary allocations. Over the years, the majority of West African countries have not met the African head of state commitment to allocate at least $15 \%$ of the annual budget to health sector. Quite confoundingly, health priority in a sizeable number of countries saw an appreciable reduction over the years as evident by Ghana, Togo, and Guinea-Bissau. The mean value for health priorities averaged by all the countries is a paltry $5.4 \%$. For a substantive number of countries, the total health expenditure is far less than the bare minimum of $\$ 34$ per person per year recommended by the WHO Macroeconomics and Health [17].

Healthcare is not a luxury but rather a necessity and this critical underfunding of health correlates with negative life expectancy and economic growth retardation profoundly battling the West African countries [18]. All these regions are faced with numerous health problems including healthcare workers shortages, poorly equipped primary healthcare facilities, incessant brain drain, political flux, drug shortages [19], widespread use of fake drugs, high maternal and child mortalities, the burden of infectious diseases, and poverty and low standard of living [20]. All these stem from a shortage of health expenditure exacerbated by the inefficient use of existing resources, lack of effective social protection mechanism to ensure equitable distribution of

Table 2 Assessment of health priorities in The Economic Community of West African States from 2010 to 2018

\begin{tabular}{|c|c|c|c|c|c|c|c|c|c|c|}
\hline \multirow[t]{2}{*}{ Country } & \multicolumn{9}{|c|}{ Health priority (\%) } & \multirow{2}{*}{$\begin{array}{l}\text { Average health } \\
\text { priorities from } \\
2010-2018\end{array}$} \\
\hline & 2010 & 2011 & 2012 & 2013 & 2014 & 2015 & 2016 & 2017 & 2018 & \\
\hline Benin & 5.15 & 5.40 & 5.25 & 5.13 & 4.04 & 3.23 & 3.73 & 4.58 & 2.96 & 4.39 \\
\hline Ghana & 11.91 & 12.09 & 8.97 & 8.64 & 6.72 & 8.56 & 6.54 & 6.04 & 6.42 & 8.43 \\
\hline Nigeria & 2.69 & 2.76 & 3.87 & 3.66 & 3.53 & 5.32 & 5.00 & 4.44 & 4.44 & 3.96 \\
\hline Burkina Faso & 6.03 & 6.59 & 4.70 & 6.38 & 7.77 & 7.15 & 11.03 & 9.99 & 8.78 & 7.60 \\
\hline Cabo Verde & 7.23 & 8.61 & 8.86 & 9.03 & 9.98 & 10.09 & 10.39 & 10.39 & 10.39 & 8.29 \\
\hline Cote d'Ivoire & 4.06 & 4.39 & 4.62 & 4.59 & 5.11 & 4.75 & 4.82 & 5.10 & 5.07 & 4.72 \\
\hline The Gambia & 6.13 & 6.13 & 6.13 & 6.13 & 5.75 & 5.10 & 6.23 & 4.38 & 4.38 & 5.59 \\
\hline Liberia & 3.17 & 5.05 & 2.84 & 1.03 & 2.51 & 3.25 & 3.90 & 4.20 & 5.23 & 3.46 \\
\hline Togo & 7.45 & 5.67 & 6.11 & 5.01 & 5.07 & 4.16 & 4.26 & 4.26 & 4.26 & 5.14 \\
\hline Mali & 3.30 & 2.94 & 2.66 & 4.13 & 4.45 & 4.39 & 5.43 & 5.43 & 5.43 & 4.24 \\
\hline Niger & 8.70 & 8.94 & 6.25 & 6.56 & 5.40 & 4.59 & 5.69 & 9.66 & 8.35 & 7.13 \\
\hline Senegal & 5.35 & 5.63 & 5.31 & 5.30 & 4.68 & 4.69 & 4.46 & 4.26 & 4.26 & 4.88 \\
\hline Guinea & 1.77 & 3.18 & 2.57 & 2.62 & 3.03 & 1.98 & 4.11 & 4.11 & 4.11 & 3.05 \\
\hline Sierra Leone & 6.29 & 4.13 & 4.68 & 5.15 & 7.58 & 7.91 & 7.91 & 7.91 & 7.25 & 6.53 \\
\hline Guinea-Bissau & 5.94 & 2.87 & 4.20 & 4.72 & 2.89 & 2.78 & 2.68 & 3.01 & 3.02 & 3.56 \\
\hline
\end{tabular}

Source: Authors' compilation from World Health Organization Global Health Expenditure Database 


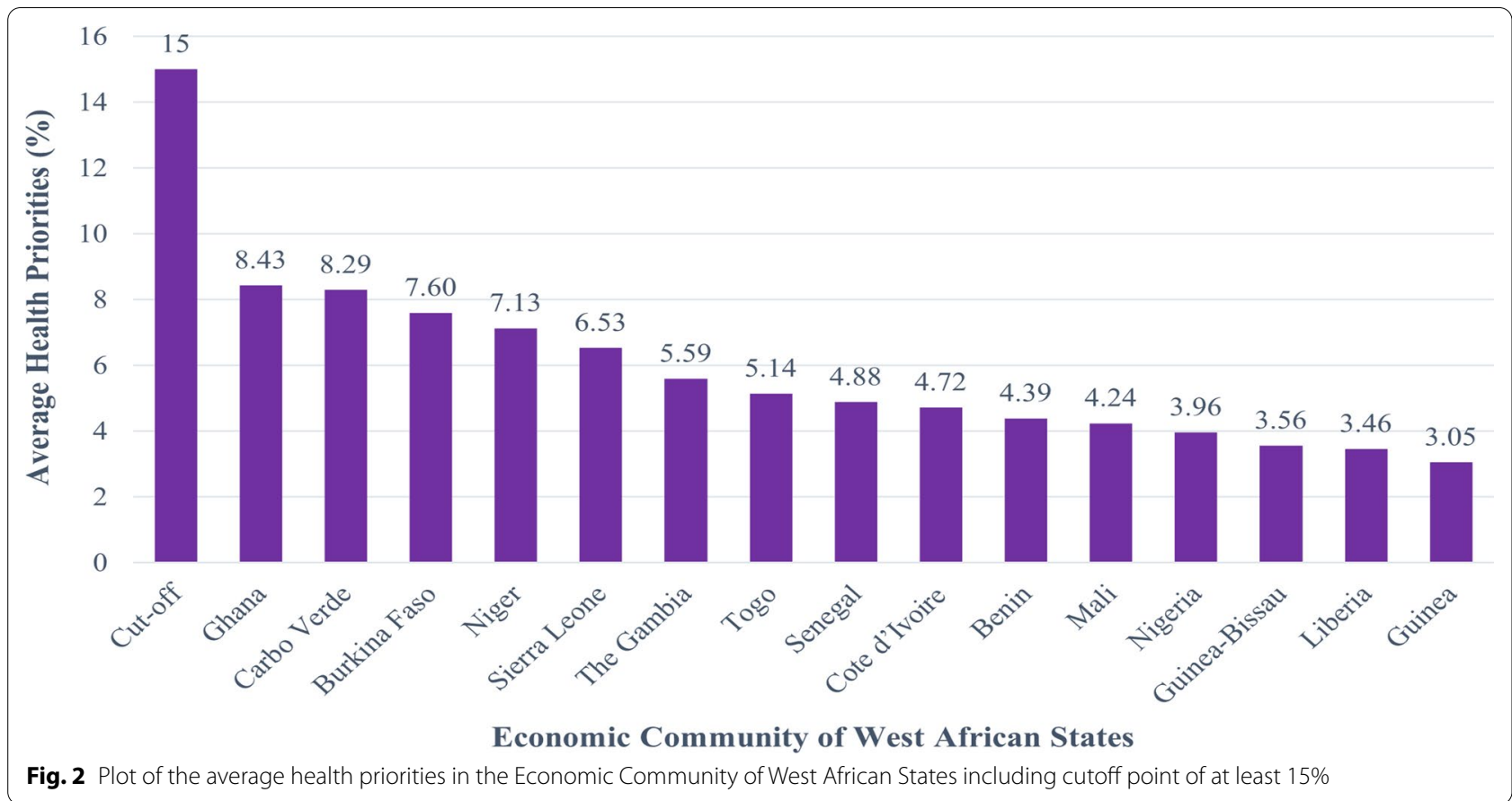

healthcare, gross incapability to implement national policies, nepotism, and deficient political moxie.

Primarily, the lack of investment by the government on the healthcare system has also resulted into weak insurance systems on the continent $[3,6]$. In many West African Countries, the out-of-pocket payment resulting in catastrophic spending is worrisome, even though there are various public and private insurance establishments [3]. This is concerning, because uninsured patients are at the mercy of an inefficient health system indicating an overall lack of health priority by the government.

\section{Reason for this state of health priority}

Health indices in West Africa are worrisomely by far the lowest in the world and the health expenditure is abysmally discouraging. It becomes expedient to analyze the reason for this to derive the implications on UHC. Micah and colleagues [21] considered seven major factors influencing health budgetary allocation, namely: inadequate national income, profligate general government expenditure on non-health-related sectors, inadequate external revenue and assistance for health, limited government tax revenue caused by large informal sectors vis-à-vis small formal sectors, profound corruption in the public sector, unfavorable time trend, and huge population structure. At the heart of these factors lie government low health financing; low investment in other sectors that influence social determinants of health including water and sanitation, food security, and housing; preponderant un-pooled out-of-pocket spending; ineffectual health insurance schemes; inefficient health programme integration; and poor health strengthening systems approach.

\section{Implications for Universal Health Coverage}

Achieving UHC is a major target every country in the world aimed to attain when adopting the SDGs in 2015. This implies that all individuals and communities will have access to healthcare without suffering financial hardship, as such promote health equity [16]. This concept, as laudable as it is, is heavily dependent on the healthcare expenditure by the government of every country. With the inadequate health priority as observed in the West African countries, the core objectives of UHC become encumbered with challenges. One of such objectives is financial protection which implies that the cost of assessing medical services should not impact negatively on the recipients. This is to ensure that all individuals have sufficient access to healthcare needs without significant out-of-pocket spending to obtain healthcare. This is usually achieved by risk pooling through tax-funded or social health insurance schemes $[3,22]$. In most West African countries, un-pooled sources include out-ofpocket spending in the forms of payment for medical products and services accounts for up to $30 \%$ to $70 \%$ of total health expenditure [3]. The reliance on out-ofpocket spending significantly impedes access to healthcare and predisposes the population to impoverishment $[22,23]$. 
Another important aim of UHC is to ensure equitable access to health services through adequate provision of quality preventive and treatment healthcare services as at when due without denial in access due to lack of healthcare facility, supplies, and manpower [3]. In addition, from every indication, West African countries' low health prioritization mount a huge roadblock against this aim as evident by its characteristic deficient health facilities, low drug availabilities, heavy shortage of healthcare practitioners, dilapidated health institutions, and enormous vulnerable population, resulting in very low confidence in the struggle to achieve UHC.

\section{Recommendations}

Having established the dire state of health priority in West African countries, we identify various means of ameliorating this swathe of problems. These include but are not limited to improvement of the government's commitment to providing adequate and necessary healthcare through the strengthening of their willpower and imperative to fill the huge gaps in healthcare provision and financing; investment in strengthening the region's primary healthcare systems; provision of incentive to private health sectors to alleviate their huge cost of health services; implementation of strong monitoring framework that ensures prudent utilization of government expenditure on health and to curb incompetence and corruption in budgeting, planning, accounting, auditing, monitoring and evaluation at all levels; a capacity building that ensures the development of prepaid health financing systems including social health insurance, community health insurance, and tax-funded systems to cushion households against catastrophic and impending pauperization.

The indicators of health in West Africa countries are abysmal. We have a picture of a region plagued with diverse health problems and concomitant morbidities and mortalities. Despite the availability of policies and initiatives steered towards accentuating governments' priority on health through budgetary allocations, there has been an underwhelming outcome on health indices in the region. This is largely a function of the government's failure to allocate an appreciable quota of their budget on health. Consequently, the proportion of individuals who can afford the astronomical cost of healthcare continue to spend hugely to obtain even the basic healthcare services at a suboptimal level, while the proportion of those who cannot afford healthcare continues to escalate. This directly contradicts the aims and objectives of the UHC and SDGs. Thus, it becomes imperative to anatomize the crux of this perpetual problem. Consensus materialized on several key actions that must be taken to allay impending negative health implications on the West African subcontinent. Every country must develop a comprehensive health financing strategy with a clear roadmap for attaining the UHC vision. Countries must make concerted efforts to abide by the policies that ensure that at least $15 \%$ of their annual budget is allocated to health. A monitoring framework that regulates government allocation and ensures judicious utilization of government expenditure must be reinstated to curb excesses, defiance, and libertine misuse of government resources. Only then will the West Africa region liberate itself from the constraints of ill-health and begin the journey towards development on par with contemporaneous regions of the world.

\section{Conclusion}

This study emphasized the need for West African governments and other relevant stakeholders to prioritize health in their political agenda towards achieving UHC. It is also important that every country in the region develop a comprehensive health financing strategy with a clear roadmap for attaining the UHC vision.

\section{Acknowledgements}

Not applicable.

\section{Authors' contributions}

YAA: Conceptualization; data curation; formal analysis; investigation; methodology; project administration; supervision; visualization; writing —original draft; writing - review and editing. $A A$ and $A B$ : data curation; formal analysis; visualization; writing — review and editing. $\mathrm{AOB}, \mathrm{NE}, \mathrm{AUE}, \mathrm{IOO}$ and $\mathrm{OO}$ : data curation; methodology; writing - review and editing. SKM, TA, OAO, OCO and DEL-PIII: revised and reviewed the paper; wrote the paper. All authors read and approved the final manuscript.

\section{Funding}

None.

Availability of data and materials Not applicable.

\section{Declarations}

Ethics approval and consent to participate Not applicable.

Consent for publication

All authors agreed to the publication of this manuscript.

Competing interests

We declared no competing interests.

\section{Author details}

${ }^{1}$ African Young Leaders for Global Health, Abuja, Nigeria. ${ }^{2}$ Global Health Focus, Kigali, Rwanda. ${ }^{3}$ Faculty of Pharmacy, University of Ibadan, Ibadan, Nigeria. ${ }^{4}$ Faculty of Pharmaceutical Sciences, University of Ilorin, Ilorin, Nigeria. ${ }^{5}$ National Primary Healthcare Development Agency, Abuja, Nigeria. ${ }^{6}$ Centre for Tropical Medicine and Global Health, University of Oxford, Oxford, UK. ${ }^{7}$ Department of Child Health, Tamale Teaching Hospital, Tamale, Ghana. ${ }^{8}$ Faculty of Pharmaceutical Sciences, University of Uyo, Uyo, Nigeria. ${ }^{9}$ Department of Microbiology, University of Ilorin, Ilorin, Nigeria. ${ }^{10}$ Faculty of Public Health, College of Medicine, University of Ibadan, Ibadan, Nigeria. ${ }^{11}$ Faculty of Pharmaceutical Sciences, Ahmadu Bello University, Zaria, Nigeria. ${ }^{12}$ College of Medical, Veterinary and Life Sciences, University of Glasgow, Glasgow, UK. 
${ }^{13}$ Force Headquarters, Police Medical Services, Falomo Hospital, Ikoyi, Lagos, Nigeria. ${ }^{14}$ Department of Global Health and Development, London School of Hygiene and Tropical Medicine, London, UK.

Received: 27 September 2021 Accepted: 19 October 2021 Published online: 26 October 2021

\section{References}

1. Anaemene B. Health and diseases in Africa. In: The development of Africa: issues, diagnoses and prognoses. vol. 71. 2017. p. 207-26.

2. Adebisi YA, Ekpenyong A, Ntacyabukura B, Lowe M, Jimoh ND, Abdulkareem TO, Lucero-Prisno DE. COVID-19 highlights the need for inclusive responses to public health emergencies in Africa. Am J Trop Med Hyg. 2020;104(2):449-52. https://doi.org/10.4269/ajtmh.20-1485 (Advance online publication).

3. Adebisi YA, et al. Assessment of health budgetary allocation and expenditure toward achieving universal health coverage in Nigeria. Int J Health Life Sci. 2020. https://doi.org/10.5812/ijhls.102552.

4. WHO. Trends in maternal mortality: 1990 to 2015 Estimates by WHO, UNICEF, UNFPA, World Bank Group and the United Nations Population Division. 2015. https://www.who.int/reproductivehealth/publications/ monitoring/maternal-mortality-2015/en/. Accessed 27 Apr 2021.

5. UNICEF. Under-five mortality. 2020. https://data.unicef.org/topic/childsurvival/under-five-mortality/. Accessed 27 Aug 2021.

6. Dadjo J, Omonaiye O, Yaya S. Health insurance coverage and access to child and maternal health services in West Africa: a study protocol for a systematic review. Syst Rev. 2021;10(1):74.

7. Avert. HIV AND AIDS IN WEST AND CENTRAL AFRICA OVERVIEW. 2020. https://www.avert.org/hiv-and-aids-west-and-central-africa-overview. Accessed 27 Apr 2021

8. Adebisi YA, Agumage I, Sylvanus TD, Nawaila IJ, Ekwere WA, Nasiru M, et al. Burden of tuberculosis and challenges facing its eradication in West Africa. Int J Infect. 2019:6(3):e92250.

9. African Union. Abuja Declaration in 2001. https://au.int/sites/default/files/ pages/32894-file-2001-abuja-declaration.pdf. Accessed 27 Sept 2021.

10. WHO. 'The Abuja Declaration: Ten Years On', 2021. 2011. pp. 1-4. https:// www.who.int/healthsystems/publications/abuja_report_aug_2011.pdf. Accessed 27 Aug 2021.

11. Piatti-Fünfkirchen $M$, Lindelow $M$, Yoo K. What are governments spending on health in east and Southern Africa? Health Syst Reform. 2018;4(4):28499. https://doi.org/10.1080/23288604.2018.1510287.

12. Stenberg $\mathrm{K}$, et al. Financing transformative health systems towards achievement of the health Sustainable Development Goals: a model for projected resource needs in 67 low-income and middle-income countries. Lancet Glob Health. 2017;5(9):e875-87. https://doi.org/10. 1016/S2214-109X(17)30263-2.

13. Huynen MM, Martens $P$, Hilderink HB. The health impacts of globalization: a conceptual framework. Glob Health. 2005;1:14. https://doi.org/10.1186/ 1744-8603-1-14.

14. WHO. Ouagadougou declaration on Primary Health Care and health systems in Africa: achieving better health outcomes for Africa in the new millennium. 2008. https://www.afro.who.int/publications/ouagadougoudeclaration-primary-health-care-and-health-systems-africa. Accessed 27 Apr 2021.

15. Taskforce on Innovative International Financing for Health Systems. Constraints to scaling up and costs: working group 1 report. Geneva. 2009. http://www.internationalhealthpartnership.net//CMS_files/documents/ working_group_1___report_EN.pdf. Accessed 27 Apr 2021.

16. WHO. Universal Health Coverage. 2015. https://www.who.int/newsroom/fact-sheets/detail/universal-health-coverage-(uhc). Accessed 27 Apr 2021.

17. Sambo LG, Kirigia JM, Ki-Zerbo G. Health financing in Africa: overview of a dialogue among high level policy makers. BMC Proc. 2011;5(Suppl 5):S2. https://doi.org/10.1186/1753-6561-5-S5-S2.

18. Nwakanma PC, Nnamdi KC. HealthCare Financing and Health Profile in West African Countries By. 2013. pp. 1-24. http://cega.berkeley.edu/ assets/miscellaneous_files/5-ABCA-Nnamdi-HealthCare_Financing_and_ Health_Profile_in_WAfr.pdf. Accessed 27 Apr 2021.

19. Akande-Sholabi W, Adebisi YA. The impact of COVID-19 pandemic on medicine security in Africa: Nigeria as a case study. Pan Afr Med J. 2020;35(Suppl 2):73. https://doi.org/10.11604/pamj.supp.2020.35.2.23671.

20. Lucero-Prisno DE 3rd, Adebisi YA, Lin X. Current efforts and challenges facing responses to 2019-nCoV in Africa. Glob Health Res Policy. 2020;5:21. https://doi.org/10.1186/s41256-020-00148-1.

21. Micah AE, Chen CS, Zlavog BS, Hashimi G, Chapin A, Dieleman JL. Trends and drivers of government health spending in sub-Saharan Africa, 1995-2015. BMJ Glob Health. 2019;4(1):e001159. https://doi.org/10.1136/ bmjgh-2018-001159.

22. Okpani Al, Abimbola S. Operationalizing universal health coverage in Nigeria through social health insurance. Niger Med J. 2015;56(5):305-10. https://doi.org/10.4103/0300-1652.170382.

23. Borghi J, Ensor T, Somanathan A, Lissner C, Mills A, Lancet Maternal Survival Series Steering Group. Mobilising financial resources for maternal health. Lancet (Lond, Engl). 2006;368(9545):1457-65. https://doi.org/10. 1016/S0140-6736(06)69383-5.

\section{Publisher's Note}

Springer Nature remains neutral with regard to jurisdictional claims in published maps and institutional affiliations.
Ready to submit your research? Choose BMC and benefit from:

- fast, convenient online submission

- thorough peer review by experienced researchers in your field

- rapid publication on acceptance

- support for research data, including large and complex data types

- gold Open Access which fosters wider collaboration and increased citations

- maximum visibility for your research: over $100 \mathrm{M}$ website views per year

At BMC, research is always in progress.

Learn more biomedcentral.com/submissions 